\title{
Perencanaan Pengembangan Industri Skala Kecil Fillet Ikan Tuna (Tunnus sp) di Kabupaten Manokwari
}

\author{
Planning for the Development of Small-scale Tuna Fish (Tunnus sp) Fillet Industry in \\ Manokwari Regency
}

\author{
Ngaliman $^{1}$, Fitryanti Pakiding ${ }^{2 *}$, Isak Silamba ${ }^{2}$ \\ ${ }^{1}$ Alumni Jurusan Teknologi Hasil Pertanian, Fakultas Teknologi Pertanian, Universitas Papua \\ ${ }^{2}$ Jurusan Teknologi Hasil Pertanian, Fakultas Teknologi Universitas Papua \\ *Koresponden e-mail: f.pakiding@unipa.ac.id; fitryanti@yahoo.com
}

\begin{abstract}
Eventhough the processing technology of fishery products has been well developed over the years, the fish processing industry in Manokwari Regency has not yet developed. One of the reasons causing this underdevelopment is due to lack of knowledge and skills in managing such business. Hence, to contribute to the lack of information available for the development of fish industry in this region, this study aims to examine the feasibility of establishing a tuna fillet industry in Manokwari Regency. This feasibility study covers aspects such as: technology, marketing and finance. The aspects of technical and technological feasibility as well as market and marketing are examined using descriptive methods, while the financial aspects are examined using financial indicators such as IRR, NPV, and B / C Ratio. The results of data analysis on these three aspects indicate that small scale tuna fillet industry is feasible to established in Manokwari. This recommendation is valid when taking into account the technological aspects that streamline the production process with the target market is export market through collectors in bigger cities in Indonesia. Financially, this small tuna fillet industry is feasible to operate with an investment period of 3 years; a payback period of 2 years and 7 months; IRR value greater than the investment interest rate; NPV is greater than zero during the investment time; and $B / C$ ratio of 1.15. The sensitivity analysis shows that this industry will remain financially viable to be established if there is a change in raw material prices by $20 \%$ and a decline in product prices by $10 \%$.
\end{abstract}

Keywords: small industry feasibility, tuna fish fillets, UMKM Manokwari.

\begin{abstract}
Abstrak
Walaupun teknologi pengolahan produk perikanan sudah sangat berkembang, akan tetapi, sampai saat ini industri pengolahan ikan di Kabupaten Manokwari, belum berkembang. Salah satu penyebab kurang berkembangnya industri perikanan adalah kurangnya pengetahuan dan keterampilan mengelola usaha termasuk pendirian usaha pengolahan produk perikanan. Oleh karena itu, penelitian ini bertujuan untuk mengkaji kelayakan pendirian industri fillet ikan tuna di Kabupaten Manokwari. Secara khusus kajian kelayakan ini meliputi aspek: teknis dan teknologi, pasar dan pemasaran, dan finansial. Aspek kelayakan teknis dan teknologi serta pasar dan pemasaran dikaji menggunakan metode deskriptif, sedangkan aspek finansial dikaji menggunakan indikator finansial seperti IRR, NPV, dan Rasio B/C. Hasil analisa menunjukkan bahwa industri kecil fillet ikan tuna layak didirikan di Kabupaten Manokwari dengan memperhatikan aspek teknis dan teknologi yang mengefisienkan proses produksi dengan sasaran pasar adalah pasar ekspor melalui kota-kota besar di Indonesia. Secara finansial, industri ini layak beroperasi dalam masa waktu investasi 3 tahun; nilai payback 2 tahun 7 bulan; nilai IRR yang lebih besar dari suku bunga investasi; dan NPV lebih besar dari
\end{abstract}


nol; dan $\mathrm{B} / \mathrm{C}$ ratio sebesar 1,15. Analisis sensitivitas yang dilakukan menunjukkan bahwa industri ini akan tetap layak secara finansial untuk didirikan apabila terjadi perubahan harga bahan baku sebesar $20 \%$ dan penurunan harga produk sebesar $10 \%$.

Kata kunci: kelayakan industri kecil, fillet ikan tuna, UMKM Manokwari.

\section{PENDAHULUAN}

Provinsi Papua Barat merupakan provinsi yang memiliki wilayah perairan yang kaya dengan sumberdaya lautnya yang menjadi sumber kehidupan bagi masyarakat yang bermukim di wilayah pesisir (Ahmadia et al, 2016). Akan tetapi disaat yang sama data menunjukkan bahwa Papua Barat merupakan salah satu provinsi termiskin di Indonesia (BPS ${ }^{\mathrm{a}}$, 2018). Oleh karena itu, diperlukan strategi dalam rangka optimalisasi pemanfaatan sumberdaya perairan untuk kesejahteraan masyarakat.

Sebagian besar masyarakat Papua Barat yang bermukim di daerah pesisir masih memanfaatkan sumberdaya perairan untuk keperluan konsumsi (Ahmadia et al, 2016). Padahal, sektor perikanan telah menjadi penyumbang dalam pendapatan Provinsi Papua Barat selama beberapa dekade (BPS $\left.{ }^{\mathrm{a}}, 2018\right)$. Fenomena ini diduga disebabkan karena sebagian besar sumbangan tersebut berasal dari sektor usaha menengah dan besar. Oleh karena itu, untuk meningkatkan manfaat potensi sumberdaya perikanan bagi kesejahteraan masyarakat maka perlu strategi sebagai upaya meningkatkan nilai tambah produk perikanan yang dapat dihasilkan oleh usaha perikanan pada skala mikro atau kecil.

Penelitian mengenai peningkatan nilai tambah produk perikanan sudah sangat berkembang yang menghasilkan pohon industri produk perikanan industri pengolahan ikan (Agustini dan Swastawati, 2003). Walaupun teknologi pengolahan ikan sudah sangat berkembang, akan tetapi, sampai saat ini industri pengolahan ikan di Papua Barat belum berkembang. Salah satu penyebab kurang berkembangnya industri pengolahan ikan diduga adalah karena kurangnya pengetahuan dan keterampilan untuk mengelola usaha (BI, 2014), termasuk di dalamnya adalah pendirian, pengembangan, dan perluasan usaha.

Upaya untuk meningkatkan nilai tambah dan mengoptimalkan pemanfaatan produksi hasil tangkapan laut untuk peningkatan pendapatan masyarakat pesisir di
Papua Barat diutamakan pada usaha dengan penggunaan teknologi dan manajemen usaha yang relatif sederhana. Salah satu bentuk olahan produk perikanan yang saat ini telah dilakukan oleh masyarakat di Kabupaten Manokwari Papua Barat adalah pengolahan fillet ikan tuna. Fillet adalah irisan daging ikan tanpa tulang yang merupakan bahan setengah jadi dari daging ikan yang nantinya akan diolah menjadi makanan lain seperti abon, bakso, dan sosis. Fillet memiliki beberapa keuntungan sebagai bahan baku olahan, antara lain daging ikan bebas duri dan tulang, umur simpan lebih lama, serta dapat menghemat waktu dan tenaga kerja karena penanganannya lebih mudah (Martha, 2006).

Sampai saat ini belum ada studi yang menginformasikan mengenai kelayakan pendirian industri fillet ikan di Kabupaten Manokwari Provinsi Papua Barat. Studi kelayakan merupakan hal yang sangat penting dilakukan pada-sektor industri dan perdagangan yang lebih bersifat komersial dan padat modal. Kekeliruan dan kesalahan dalam menilai investasi akan menyebabkan kerugian dan resiko yang besar. Penilaian inventasi termasuk dalam studi kelayakan yang bertujuan menghindari terjadinya keterlanjuran investasi yang tidak menguntungkan karena usaha yang tidak layak atau tidak feasible (Subagyo, 2007).

Tujuan umum dari penelitian ini adalah untuk mengkaji kelayakan pendirian industri fillet ikan di Kabupaten Manokwari. Sedangkan tujuan khusus penelitian ini adalah: (1) Mengkaji aspek teknis dan teknologi pendirian industri fillet ikan di Kabupaten Manokwari; (2) Mengkaji aspek pasar dan pemasaran pendirian industri fillet ikan di Kabupaten Manokwari; dan (3) mengkaji aspek finansial pendirian industri fillet ikan di Kabupaten Manokwari.

\section{METODOLOGI}

\section{Bahan dan alat}

Untuk menjawab tujuan penelitian ini maka dilakukan pengumpulan data primer pada existing industri fillet ikan, Industri Haji 
Arif yang berlokasi di Kabupaten Manokwari Provinsi Papua Barat sebagai data dasar yang dijadikan acuan dalam pengembangan skenario usaha yang akan dikembangkan. Disamping itu, data sekunder dari berbagai literatur dikumpulkan untuk mendukung pengembangan skenario instansi-instansi pemerintahan, data tersebut antara lain diperoleh dari berbagai publikasi yang diterbitkan oleh Biro Pusat Statistik atau Statistik Daerah.

\section{Pengumpulan Data}

Pengumpulan data dilakukan pada bulan Mei-Juli 2015, selanjutnya data digunakan untuk mengkaji kelayakan pendirian industri fillet ikan. Data yang dikumpulkan meliputi aspek teknis dan teknologi, pemasaran, dan finansial.

\section{Variabel Penelitian}

Untuk mendapatkan gambaran kelayakan industri fillet ikan, beberapa variabel yang diamati pada industri yang eksisting, antara lain :

1. Aspek pasar dan pemasaran yang meliputi potensi dan peluang pasar.

2. Aspek teknis dan teknologi yang meliputi potensi bahan baku, teknik pengolahan dan tata letak pabrik.

3. Aspek finansial meliputi kebutuhan dana investasi, biaya tenaga kerja, depresiasi, biaya produksi, modal kerja, dan biaya kredit, serta kelayakan dengan metode PP, IRR, NPV, PI, BEP. Metode-metode ini umum digunakan dalam menghitung kelayakan finansial pada berbagai studi (Martha (2006); Ningsih et al (2013); Novia (2011); dan Hendrawati (2014)).

\section{Analisis Data}

Data yang diperoleh dianalisis sesuai dengan variabel yang diamati:

a. Aspek pasar dan pemasaran meliputi potensi dan peluang pasar dianalisis dengan metode deskriptif.

b. Aspek teknis dan teknologis meliputi lokasi pendirian industri, potensi bahan baku, dan teknik pengolahan dianalisis dengan menggunakan metode deskriptif. Tata letak pabrik dianalisis dengan menggunakan bagan keterkaitan antar aktifitas.

c. Aspek finansial dianalisis dengan menghitung BEP, NPV, IRR dan PI. Beberapa skenario perubahan-perubahan pada analisis sensitivitas diasumsikan bahwa akan ada penambahan pada biaya bahan baku utama sebesar $20 \%$ dan akan terjadinya penurunan harga jual produk sebesar $10 \%$.

Break Event Point (BEP)

$$
\begin{aligned}
\text { BEP Unit }= & \frac{F C}{P-V C} \ldots \ldots \ldots \ldots \ldots \ldots \ldots(1) \\
\text { FC } & =\text { Fixed Cost (biaya tetap) } \\
\mathrm{P} & =\text { Price }(\text { harga jual) } \\
\mathrm{VC} & =\text { Variabel Cost (biaya tidak } \\
\text { tetap) } &
\end{aligned}
$$

$$
\begin{aligned}
& \text { Payback Periode }(\mathrm{PP}) \\
& \begin{aligned}
& P P=\left(t+\frac{b-c}{d-c}\right) \times 12 \text { bulan .............. (2) } \\
& \mathrm{b}=\text { initial investment }(\text { modal awal) } \\
& \mathrm{c}=\text { kumulatif } \text { net cash inflow tahun ke } \mathrm{t} \\
& \mathrm{d}=\text { kumulatif } \text { net cash inflow tahun } \mathrm{t}+1 \\
& \mathrm{t}=\text { tahun terakhir dimana komulatif } n e t \\
& \text { cash belum mencapai } \text { initial investment }
\end{aligned}
\end{aligned}
$$

Net Present Value (NPV)

$$
\begin{aligned}
& N P V=\sum_{t=1}^{n}\left((\mathrm{Bt}-\mathrm{Ct}) /(1+i)^{k}\right) \ldots . . \\
& \mathrm{Bt}=\text { Manfaat proyek pada tahun } \mathrm{t} \\
& \mathrm{Ct}=\text { Biaya proyek pada tahun } \mathrm{t} \\
& \mathrm{n}=\text { Umur ekonomis proyek } \\
& \mathrm{i}=\text { Tingkat bunga } \\
& \mathrm{t}=\text { Tahun } \\
& \text { apabila diperoleh: }
\end{aligned}
$$

NPV > 0, maka proyek layak diteruskan

NPV $<0$, maka proyek tidak layak

Internal Rate of Return (IRR)

$$
I R R=i^{\prime \prime}+\frac{N P V^{\prime}}{N P V^{\prime}-N P V^{\prime \prime}}+\left(i^{\prime \prime}-i^{\prime}\right) \ldots \ldots .
$$

IRR = Tingkat keuntungan internal NPV' = Nilai Rp pada tingkat bunga terendah dengan NPV positif

NPV"= Nilai Rp pada tingkat bunga tertinggi dengan NPV negatif

i' = Tingkat bunga terendah yang memberikan nilai NPV positif

i” = Tingkat bunga tertinggi yang memberikan nilai NPV negative

Apabila diperoleh :

IRR $>$ i, maka proyek layak diteruskan IRR $<$ i, maka tidak layak diteruskan

Profitability Index (PI)

$P I=\left(\frac{P V \text { kas masuk }}{P V \text { kas keluar }}\right)$. 
Jika PI $>1$, maka menguntungkan

PI $<1$, maka tidak menguntungkan

\section{HASIL DAN PEMBAHASAN}

Hasil pengamatan pada penelitian ini disampaikan dalam dua bagian: bagian pertama menguraikan hal-hal yang telah dikaji pada industri fillet ikan tuna Haji Arif, bagian kedua diuraikan hasil analisis kelayakan sesuai dengan skenario yang dikembangkan dalam penelitian ini.

\section{Keadaan Industri Fillet Ikan Tuna Haji Arif}

Industri fillet ikan Haji Arif merupakan salah satu industri yang bergerak dibidang perikanan yang berada di wilayah Kabupaten Manokwari. Industri ini mengelolah ikan tuna utuh menjadi fillet ikan tuna. Berikut ini adalah hasil pengamatan beberapa aspek penting suatu industri di Industri fillet ikan Haji Arif:

\section{Aspek Teknis dan Teknologi}

Aspek teknis dan teknologi yang diteliti meliputi bahan baku, teknik pengolahan, tata letak pabrik yang akan diuraikan sebagai berikut:

\section{Bahan Baku}

Bahan baku industri adalah ikan tuna segar yang diperoleh langsung dari nelayan yang mengantar ke lokasi pabrik dengan harga Rp.10.000 s/d Rp.30.000/kg. Penentuan harga ini disesuaikan dengan kualitas daging ikan tuna yang dijual oleh para nelayan. Ikan yang diterima minimal beratnya $10 \mathrm{~kg} /$ ekor. Jumlah ikan tuna yang dibeli mencapai rata-rata 500 kg per hari

\section{Teknik Pengolahan}

Pengolahan fillet ikan dilakukan setiap hari dengan rata-rata produksi per hari adalah $250 \mathrm{~kg}$ fillet ikan tuna. Proses pengolahan fillet ikan tuna dilakukan secara manual. Peralatan yang digunakan untuk pengolahan antara lain timbangan, pisau, batu gosok, ember, gayung dan cool box.

\section{Tata Letak Pabrik}

Tata letak dan aliran proses produksi fillet ikan tuna pada industri pengolahan fillet ikan tuna Haji Arif sudah berurutan sesuai dengan tahap-tahapannya (Martha, 2006), namun belum dilakukan pembagian tempat untuk masing-masing tahap produksi, sehingga beberapa tahap produksi masih menggunakan tempat yang sama.

\section{Aspek Pasar dan Pemasaran}

Pemasaran fillet ikan tuna yang dihasilkan dijual ke pedagang pengumpul di Kota Makassar dengan harga fillet tuna $\mathrm{Rp}$ $45.000 \mathrm{~s} / \mathrm{d}$ Rp 95.000/kg. Harga fillet ikan disesuaikan dengan kualitas fillet (Atase Perdagangan Indonesia, 2015). Industri fillet tuna Haji Arif mampu mengirim fillet sebanyak 25 cool box atau sekitar $250 \mathrm{~kg}$ fillet tuna perhari, menggunakan pesawat pada proses pengiriman dengan biaya Rp. $13.000 / \mathrm{kg}$.

\section{Aspek Finansial}

Dana investasi, biaya tenaga kerja, dan biaya produksi yang dikeluarkan oleh Industri fillet Tuna Haji Arif adalah sebagai berikut:

\begin{tabular}{ll}
\hline \multicolumn{1}{c}{ Aspek Finansial } & \multicolumn{1}{c}{ Jumlah } \\
\hline Dana Investasi & Rp. 30.000 .000 \\
Bangunan & Rp 5.000 .000 \\
$\begin{array}{l}\text { Mesin dan Peralatan } \\
\text { Pengadaan fasilitas }\end{array}$ & Rp. 2.000 .000 \\
$\begin{array}{l}\text { Biaya tenaga kerja } \\
\text { Tenaga kerja langsung } 2\end{array}$ & \\
$\begin{array}{l}\text { orang } \\
\text { Tenaga kerja tidak }\end{array}$ & Rp. 3.000.000/bulan \\
langsung 2 orang & Rp. 3.000.000/bulan \\
Biaya produksi & Rp.97.500.000/bulan \\
$\begin{array}{l}\text { Biaya transportasi } \\
\text { Pajak }\end{array}$ & Rp. 350.000/bulan \\
Biaya bahan Baku & Rp.450.000.000/bulan \\
\hline
\end{tabular}

Hasil observasi yang dilakukan terhadap keadaan industri fillet ikan tuna Haji Arif, menunjukkan bahwa masih terdapat beberapa masalah dan juga kendala pada aspek-aspek yang ada seperti aspek pasar dan pemasaran, aspek teknis dan teknologi, dan aspek finansial. Oleh karena itu, bagian selanjutnya dari bagian pembahasan ini adalah menyampaikan rekomendasi pengembangan industri pengolahan fillet ikan tuna berdasarkan data dan informasi yang sudah dikumpulkan pada industri fillet ikan tuna Haji Arif.

\section{Rekomendasi Pendirian Industri Fillet Ikan Tuna}

Aspek Teknis dan Teknologi

Kasmir dan Jakfar (2005) menyatakan bahwa kajian aspek teknis dan teknologi bertujuan antara lain untuk menentukan aliran bahan baku; menentukan lay-out yang sesuai 
dengan proses produksi yang efisien, menentukan teknologi yang tepat dalam proses produksi, dan menentukan kualitas tenaga kerja yang dibutuhkan sekarang dan masa mendatang. Penelitian ini hanya mengkaji aspek teknis dan teknologi dari segi potensi bahan baku, teknologi proses dan pengaturan tata letak pabrik pengolahan dalam mengembangkan kelayakan pengembangan industri fillet ikan tuna di Kota Manokwari.

\section{Potensi Bahan Baku}

Ikan tuna yang digunakan sebagai bahan baku diperoleh dari nelayan yang berasal dari daerah di sekitar Pantai Utara Kabupaten Manokwari. Kapasitas usaha direncanakan sebesar $300 \mathrm{~kg}$ fillet ikan tuna per hari dengan jumlah bahan baku yang digunakan yaitu 550 $\mathrm{kg} / \mathrm{hari}$, dengan berat minimal ikan per ekornya yaitu $10 \mathrm{~kg}$. Ikan Tuna merupakan jenis ikan dengan jumlah produksi tertinggi di antara semua jenis perikanan laut di Kabupaten Manokwari (BPS $\left.{ }^{\mathrm{b}}, 2018\right)$. Produksi ikan tuna tercatat 11,210 ton pada tahun 2016. Apabila industri ini dikembangkan dan produksi ikan tuna berkisar pada jumlah yang sama di tahun 2016, maka industri ini hanya menyerap sekitar 1,2\% dari total produksi ikan tuna yang ada di Kabupaten Manokwari. Oleh karena itu, peluang ketersediaan bahan baku masih relatif tersedia untuk keberlanjutan usaha ini.

\section{Teknologi Pengolahan}

Secara umum, proses pengolahan yang akan dikembangkan dari proses pengolahan yang sudah ada pada industri fillet ikan tuna Haji Arif. Pengembangan atau perubahan dalam proses produksi yang dilakukan pada industri yang akan direncanakan yaitu penambahan tahap pencucian ikan sebelum dan sesudah dilakukannya penyiangan, serta dilakukan penimbangan kembali sebelum fillet ikan tuna dikemas (Gambar 1). Tujuan penambahan tahap pencucian ikan sebelum dan sesudah dilakukan penyiangan untuk menghindari kontaminasi pada proses selanjutnya. Kemudian juga dilakukan pemisahan tempat antara proses penyiangan dengan tempat proses pemisahan kulit dan daging hitam. Hal ini dilakukan agar seminimal mungkin mencegah limbah hasil pada proses awal produksi tidak mengontaminasi proses produksi selanjutnya. Pengolahan fillet ikan tuna dilakukan setiap hari, dengan jumlah produksi yaitu $300 \mathrm{~kg}$ fillet ikan tuna per hari dengan proses pembuatan fillet secara manual.

\section{Tata Letak Pabrik}

Tata letak industri pembuatan fillet ikan tuna yang direncanakan akan dibuat sesuai dengan kebutuhan dan kelancaran dalam menjalankan suatu industri seperti tempat pengolahan, tempat penyimpanan sementara produk jadi, serta tempat untuk mengatur semua kegiatan yang ada dalam industri seperti kantor dan tempat parkir yang merupakan area yang tidak kalah penting dalam suatu industri. Tata letak pabrik akan dibuat sesuai dengan analisa keterkaitan antar aktivitas pada departemen atau unit kerja yang ada. Departemen pada industri yang akan direncanakan yaitu tempat penerimaan bahan baku (penimbangan), tempat penyiangan, tempat pemisahaan kulit dan tulang, bak penampungan air, pengemasan, pembekuan dan penyimpanan sementara, kantor, halaman parkir, tempat penyimpanan peralatan kerja, dan bak sampah. 


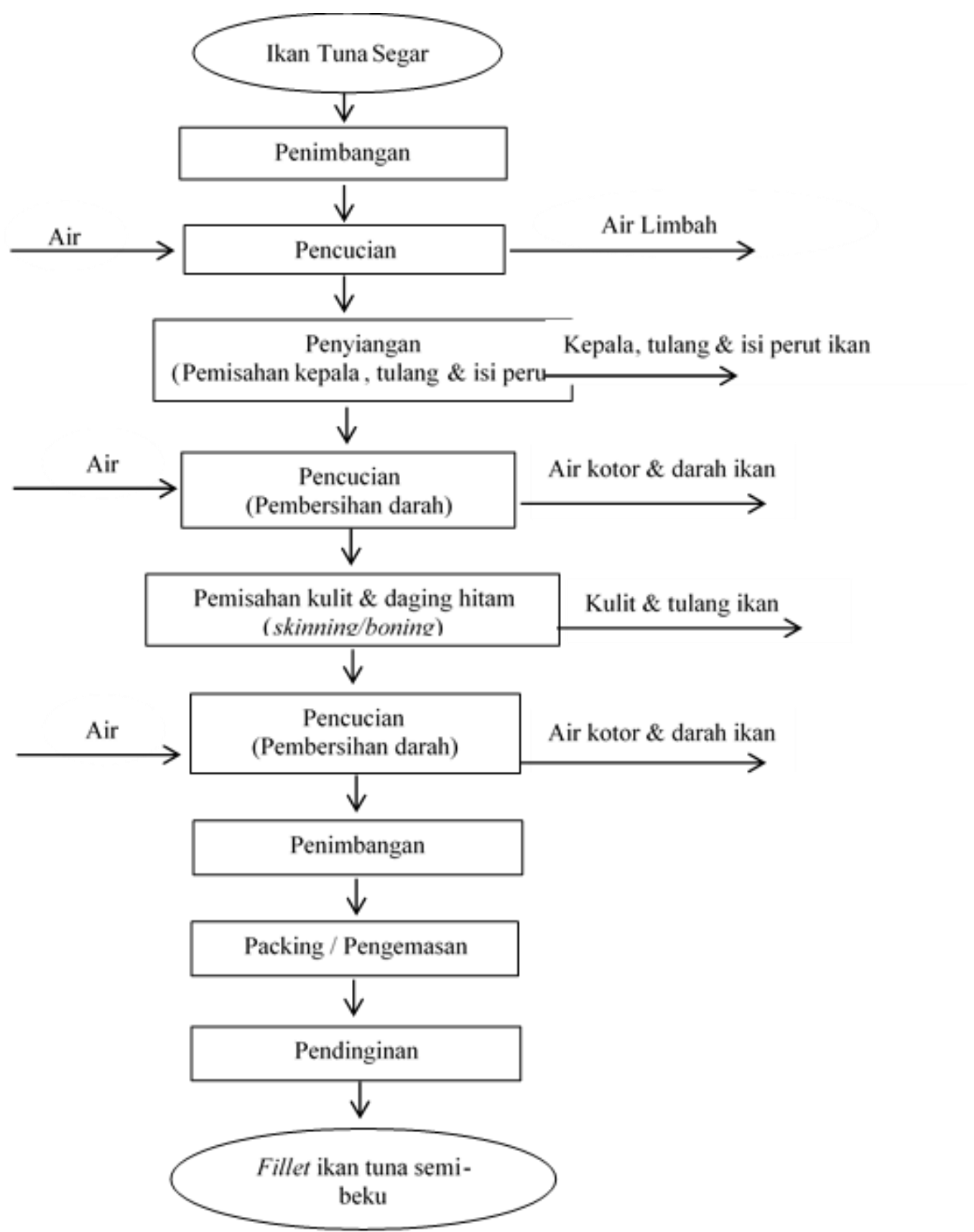

Gambar 1. Modifikasi Diagram Alir Proses Pengolahan Fillet Ikan

Tata letak pabrik dianalisa menggunakan bagan keterkaitan antar aktivitas, seberapa keterkaitan departemen kerja yang ada akan dinyatakan dengan derajat keterkaitan hubungan. Dimana derajat keterkaitan tersebut akan dinyatakan dengan simbol huruf A,E,I,O,U dan X yang mana : A (Absolut): menunjukkan bahwa letak antar kegiatan yang satu harus saling berdekatan dengan kegiatan yang lain dan bersebelahan; $\mathbf{E}$ (Especially Important): menunjukkan bahwa letak antar kegiatan harus berdekatan; I (Important): menunjukkan bahwa letak antar cukup berdekatan; O (Ordinary): menunjukkan bahwa letak antar kegiatan tidak harus saling berdekatan; U (Unimportant): menunjukkan bahwa letak antar kegiatan bebas dan tidak saling terikat; $\mathbf{X}$ (Undesirable): menunjukkan bahwa letak antar kegiatan tidak boleh saling berdekatan, atau harus saling dijauhkan (Machfud dan Agung, 1990).

Berdasarkan derajat keterkaitan dalam menganalisa hubungan aktivitas antar departemen atau unit kerja pada industri pembuatan fillet ikan tuna dengan menggunakan bagan keterkaitan antar aktivitas, diperoleh hasil analisa pada Gambar 2. Keterkaitan antar aktivitas pada industri 
pengolahan fillet ikan tuna yang dianalisis berdasarkan derajat keterkaitan antar aktivitas dengan beberapa alasan atau keterangan yang mendasari untuk menentukan derajat keterkaitan tersebut.

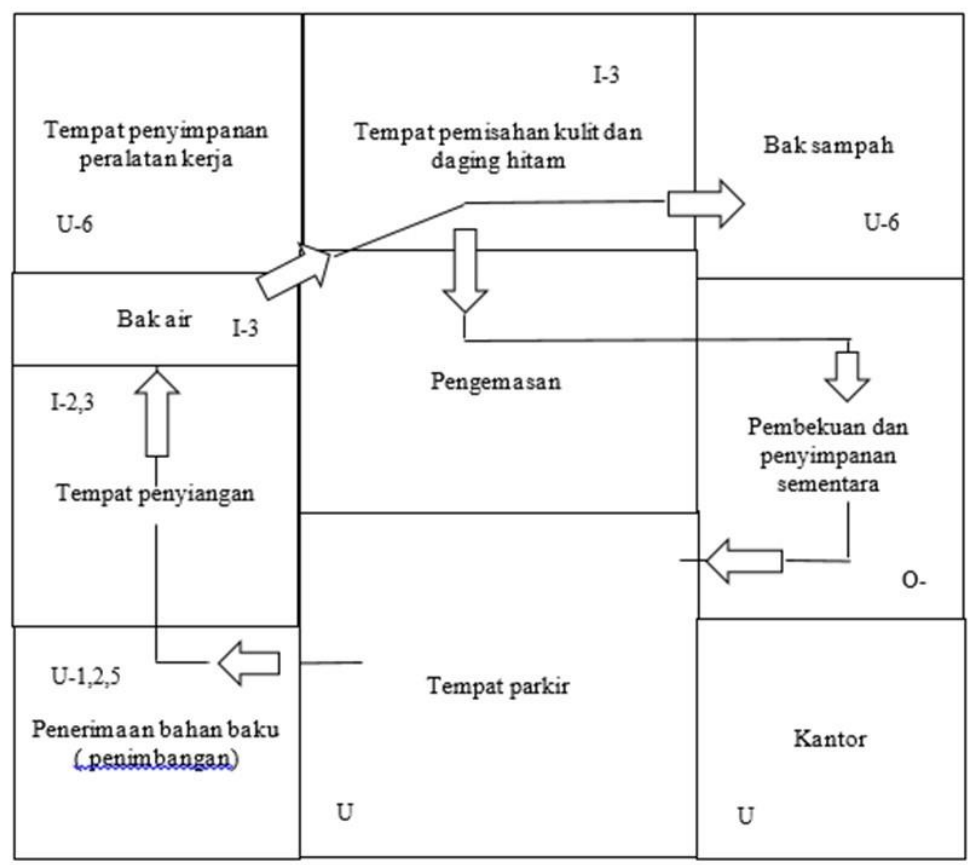

Keterangan Gambar: $\mathrm{U}=$ unimportant; $\mathrm{I}=$ important; $\mathrm{O}=$ ordinary; 1 = Urutan proses; $2=$ Penggunaan ruangan yang sama; 3 = Kebutuhan proses; 4 = Menyebabkan pencemaran; 5 = Aliran bahan; 6 =Tidak berkaitan.

Gambar 2. Tata Letak Industri Pengolahan Fillet Ikan Tuna

\section{Aspek pasar dan Pemasaran}

Aspek pasar dan pemasaran pada industri fillet ikan tuna ini akan melihat potensi peluang pasar fillet ikan tuna yang ada.

Potensi pasar ikan tuna di Kabupaten Manokwari dan di luar Kabupaten Manokwari cukup baik. Baiknya potensi pasar ikan tuna karena ikan tuna merupakan salah satu makanan yang banyak dikonsumsi, selain karena harganya yang terjangkau, ikan tuna juga masih relative tinggi produksinya, ikan juga merupakan salah satu sumber protein hewani serta kaya akan vitamin, mineral dan nutrisi yang dibutuhkan agar tubuh tetap sehat. Namun potensi pasar fillet ikan tuna di Kabupaten Manokwari relatif tidak sepotensial bila dipasarkan di luar Kabupaten Manokwari karena harga ikan tuna utuh relatif lebih murah dibandingkan dengan fillet ikan tuna. Sebuah laporan yang dikeluarkan oleh Atase Perdagangan London, Kedutaan Besar Indonesia di Inggris (2015) mencatat potensi pasar olahan ikan tuna di Inggris. Laporan ini mencatat tuna merupakan salah satu jenis ikan yang paling disukai di Inggris dan rata-rata penduduk Inggris mengonsumsi $29 \mathrm{~kg}$ ikan per tahun dan jumlah ini diperkirakan akan terus meningkat seiring dengan tren pola hidup sehat.

Sebagaimana penuturan pemilik industri, maka potensi pasar fillet ikan tuna akan lebih difokuskan di luar Kabupaten Manokwari, fillet ikan tuna yang diproduksi akan dikirim ke-pasar ekspor di Makassar. Selain itu, fillet ikan tuna akan dipasarkan di wilayah Manokwari dan sekitarnya. Untuk meningkatkan peluang pasar maka strategi yang akan dilakukan adalah peningkatan promosi dan membuka jaringan-jaringan baru. Dalam sehari pada industri yang direncanakan akan menjual fillet ikan tuna sebanyak $300 \mathrm{~kg} /$ hari, dengan harga jual Rp. 45.000- Rp. $95.000 / \mathrm{kg}$ tergantung kualitas fillet.

\section{Aspek Finansial}

Perhitungan aspek finansial pada industri kecil yang direncanakan dilakukan dengan menghitung biaya tidak tetap, seperti biaya tenaga kerja, depresiasi, biaya produksi, pembayaran kredit, perhitungan rugi laba serta perhitungan finansial. Aspek finansial ini sendiri adalah merupakan suatu gambaran 
yang bertujuan untuk menilai layak atau tidaknya suatu usaha dijalankan. Asumsiasumsi ditetapkan sebelum melakukan penilaian kelayakan industri yang akan didirikan. Asumsi-asumsinya adalah sebagai berikut:

1. Harga bahan baku ikan tuna adalah Rp. $30.000 / \mathrm{kg}$.

2. Harga pokok fillet ikan tuna adalah Rp. $95.000 / \mathrm{kg}$.

3. Umur proyek selama 5 (lima) tahun berdasarkan umur ekonomis mesin.

4. Umur ekonomis bangunan 20 (dua puluh) tahun berdasarkan UU perpajakan.

5. Tingkat suku bunga yang berlaku 20 persen.

6. Kapasitas produksi per tahun adalah $93.600 \mathrm{~kg}$ fillet ikan tuna atau $300 \mathrm{~kg}$ fillet ikan tuna per hari.

7. Tingkat produksi pada tahun pertama diperkirakan 95 persen dari total produksi yang direncanakan. Pada tahun-tahun selanjutnya produksi mencapai 100 persen dari total produksi yang direncanakan.

8. Perbandingan antara modal sendiri dan modal pinjaman adalah 70 persen dari modal sendiri dan sisanya 30 persen dari modal pinjaman.

9. Metode yang digunakan untuk menghitung depresiasi adalah metode garis lurus, dengan nilai sisa (salvage value) rata-rata 10 persen.

10. Nilai sisa pada tahun ke-5 merupakan nilai buku pada tahun tersebut.

11. Besar pajak keuntungan yang berlaku pada industri fillet ikan tuna yaitu 1 persen.

12. Masa kredit adalah 2 (dua) tahun dengan bunga 20 persen.

13. Biaya asuransi diasumsikan 3 (tiga) persen setiap tahun dari total penerimaan.

14. Biaya perawatan diasumsikan 3 (tiga) persen setiap tahun dari total penerimaan.

\section{Kebutuhan Dana Investasi}

Dana investasi merupakan dana yang dibutuhkan untuk membangun industri. Biaya investasi pada industri pengolahan fillet ikan tuna yang direncanakan meliputi pengadaan lahan, biaya pendirian bangunan, pembelian mesin dan peralatan serta fasilitas kantor:

\begin{tabular}{lll}
\hline No & Uraian & Jumlah (Rp) \\
\hline I & Investasi & \\
& Pengadaan Lahan & 50.500 .000 \\
& Bangunan & 266.000 .000 \\
& Mesin dan & 31.105 .000 \\
& Peralatan & \\
& Fasilitas & 18.000 .000 \\
Total Dana Investasi & $\mathbf{3 6 5 . 6 0 5 . 0 0 0}$ \\
\hline II & Sumber Dana \\
& Modal Sendiri & 255.923 .500 \\
& Pinjaman & 109.681 .500 \\
Total & & $\mathbf{3 6 5 . 6 0 5 . 0 0 0}$ \\
Dana & & \\
\hline
\end{tabular}

\section{Biaya Tenaga Kerja}

Biaya yang dikeluarkan untuk tenaga kerja pada industri pengolahan fillet ikan tuna meliputi biaya tenaga kerja langsung dan biaya tenaga kerja tidak langsung. Tenaga kerja langsung yang terlibat dalam proses pengolahan sebanyak 3 orang dengan biaya total per tahun Rp. 72.000.000,- sedangkan tenaga kerja tidak langsung sebanyak 5 orang dengan biaya per tahun yaitu Rp. 132.000.000,-

Depresiasi

Depresiasi merupakan penurunan dalam nilai barang atau properti seiring dengan berjalannya waktu dan penggunaannya. Depresiasi atau penyusutan terdiri dari penyusutan mesin dan peralatan, bangunan serta fasilitas kantor. Metode yang digunakan untuk menghitung penyusutan adalah metode garis lurus dengan nilai sisa (salvage vlue) yaitu sebesar 10 persen dari nilai investasi. Biaya penyusutan per tahun sebesar Rp. 23.257.500 pada tahun pertaman, dan $\mathrm{Rp}$. 15.108.000 pada tahun-tahun selanjutnya, dengan nilai sisa pada tahun ke-5 sebesar Rp. 31.210.500,--

Biaya Produksi

Biaya produksi atau operasional merupakan biaya yang dibutuhkan untuk menjalankan pabrik setelah dibangun. Biaya operasional meliputi biaya tetap dan biaya variabel. Biaya tetap pada industri ini meliputi biaya tenaga kerja, asuransi, perawatan, penyusutan dan biaya pemasaran yang besarnya Rp. 746.101.500,- dan biaya variabel meliputi bahan baku dan utilitas yang besarnya Rp. 6.527.160.000,-.

Pembayaran Kredit

Investasi pada proyek industri pengolahan fillet ikan tuna ini menggunakan dana pribadi sebesar 70 persen dan dana pinjaman dari bank sebesar 30 persen. Kredit 
investasi diterima seluruhnya pada tahun ke nol proyek dengan masa pinjaman selama dua tahun.

\section{Analisis Kelayakan Finansial}

Kriteria penilaian kelayakan yang digunakan adalah BEP, PP, NPV, IRR, PI. Hasil penilaian kelayakan adalah sebagai berikut:

\begin{tabular}{|c|c|}
\hline $\begin{array}{c}\text { Kriteria Kelayakan } \\
\text { Finansial }\end{array}$ & Nilai \\
\hline BEP & Rp. 14.429.310.329, \\
\hline PP & 2 Tahun 7 Bulan \\
\hline NPV & Rp. 2.608.711.833,- \\
\hline IRR & $145 \%$ \\
\hline PI (Net B/C ratio) & 1,15 \\
\hline
\end{tabular}

\section{Analisis Sensitivitas}

Analisis sensitivitas adalah analisis yang dilakukan untuk mengetahui akibat dari adanya perubahan pada parameter-parameter produksi terhadap perubahan kinerja produksi dalam menghasilkan keuntungan. Analisis ini dilakukan untuk mengetahui akibat yang mungkin akan terjadi dapat diketahui dan diantisipasi sebelumnya. Analisis sensitivitas pada industri pengolahan fillet ikan tuna yang direncanakan ini membuat asumsi bahwa akan terjadi kenaikan pada biaya bahan baku utama sebesar $20 \%$ dan terjadi penurunan harga jual produk sebesar $10 \%$.

Setelah melakukan perhitungan analisis sensitivitas pada NPV, IRR, dan B/C ratio diperoleh pada asumsi kenaikan biaya bahan baku utama sebesar 20\%, mempunyai nilai NPV Rp. 1.084.546.561,- dengan IRR 64\% dan untuk B/C Ratio yaitu sebesar 1,08. perhitungan analisis sensitivitas pada NPV, IRR, dan B/C Ratio dengan asumsi penurunan harga jual produk sebesar $10 \%$ mempunyai nilai NPV Rp. 162.801.760,- dengan IRR yaitu $26 \%$ dan untuk B/C Ratio sebesar 1,04. Hasil perhitungan menunjukkan bahwa pada kenaikan bahan baku utama sebesar $20 \%$ dan penurunan harga produk 10\% masih dapat diterima atau dengan kata lain industri masih layak untuk dijalankan, yaitu dengan melihat nilai NPV yang masih positif, nilai IRR yang masih sama dengan nilai suku bunga, dan nilai B/C Ratio yang $\geq 1$,

\section{KESIMPULAN}

Industri kecil fillet ikan tuna layak didirikan di Kabupaten Manokwari dengan memperhatikan aspek teknis dan teknologi yang mengefisienkan proses produksi untuk menghasilkan produk yang berkualitas. Sasaran pasar dari industri kecil fillet ikan tuna ini adalah pasar ekspor melalui pedagang pengumpul di kota besar di Indonesia, seperti Makassar. Secara finansial, industri kecil fillet ikan tuna ini layak beroperasi. secara Analisis finansial dalam masa waktu investasi 3 tahun, dengan nilai Payback Period's yang lebih kecil (2 tahun 7 bulan) dari waktu investasi; nilai IRR yang lebih besar dari suku bunga investasi; dan NPV lebih besar dari nol selama waktu investasi; dan $\mathrm{B} / \mathrm{C}$ ratio sebesar 1,15 . Analisis sensitivitas yang dilakukan menunjukkan bahwa industri ini akan tetap layak secara finansial untuk didirikan walaupun terjadi perubahan harga bahan baku sebesar $20 \%$ dan penurunan harga produk sebesar $10 \%$.

\section{DAFTAR PUSTAKA}

Agustini, T. W., dan F, Swastawati. 2003. Pemanfaatan Hasil Perikanan Sebagai Produk Bernilai Tambah (Value-Added) dalam Upaya Penganekaragaman Pangan. Jurnal Teknologi dan Industri Pangan, Vol XIV (1): 74-81

Ahmadia, G.N., L. Glew, F. Pakiding, J. Harris, N. Hidayat, E. Ihsan, W. Mangile, M. Mascia, D. Matualage, P. Mohebalian, D. Pada, Purwanto. State of the Bird's Head Seascape MPA Netwrk, 2016. World Wildlife Fund, Conservation International, The Nature Conservancy, and Universitas Papua, Washington D.C., United States, Jakarta, Indonesia, and Manokwari, Indonesia.

Atase Perdagangan London, Kedutaan Besar Indonesia di Inggris. 2015. Ikan Tuna dan Produk Olahan Tuna (Market Brief). London, Inggris.

Badan Pusat Statistik (BPS ${ }^{a}$ ). 2018. Provinsi Papua Barat dalam Angka. BPS Provinsi Papua Barat. Manokwari, Indonesia.

Badan Pusat Statistik (BPS $\left.{ }^{b}\right)$. 2018. Kabupaten Manokwari dalam Angka. BPS Kabupaten Manokwari. Manokwari, Indonesia 
Bank Indonesia (BI). 2014. Komoditas Produk Jenis Usaha Unggulan di Provinsi Papua Barat. Bank Indonesia Perwakilan Provinsi Papua dan Papua Barat. Jayapura, Indonesia.

Hendrawati, T.Y. 2011. Analisis Kelayakan Industri Alkali Treated Cotonii Chips (ATC Chips) dari Rumput Laut Jenis Euchema cotonii. Prosiding Seminar Nasional Sains dan Teknologi 2014, Fakultas Teknik Universitas Muhammadiyah Jakarta, 12 November 2014: 1-7

Kasmir dan Jakfar. 2005 .Studi Kelayakan Bisnis. Kencana. Jakarta.

Machmud dan Yudha Agung. 1990. Perancangan Tata Letak pada Industri Pangan. Departemen Pendidikan dan Kebudayaan, Direktorat Jenderal Pendidikan Tinggi, Pusat Antar Universitas Pangan dan Gizi, Institut Pertanian Bogor. Bogor. Indonesia.
Martha, R. 2006. Analisa Kelayakan Industri Fillet Ikan Patin Beku (Pangasius hypophthalmus) di Kabupaten Bogor (Skripsi). Fakultas Teknologi Pertanian. Institut Pertanian Bogor. Bogor, Indonesia.

Ningsih, R.S., A.K. Mudzakir, dan A. Rosyid. 2013. Analisis Kelayakan Finansial Usaha Perikanan Payang Jabur (Boat seine). Journal of Fisheries Resources Utilization Management and Technology, Vol. 2 (3): 223-232.

Novia, C. 2011. Kajian Kelayakan Teknis dan Finansial Produksi Nugget Jamur Tiram Putih (Pleurotus ostreatus) Rasa Ikan Tongkol (Euthynus aletrates) Skala Industri Kecil. Jurnal Teknologi Pangan, Vol 2(1): 31-49.

Subagyo, A. 2007. Studi Kelayakan. PT Elex Media Komputindo. Jakarta. 